\title{
Pteknokultura
}

\#KuHn, S. (2016). Fiber Arts and Generative Justice, Revista Teknokultura Vol. 13(2), 461-489.

Recibido:

Aceptado con modificaciones:

Aceptado finalmente:
05-06-2016 Open peer review

14-07-2016 http://revistas.ucm.es/index.php/TEKN/pages/view/opr-52809

12-10-2016

\section{Fiber Arts and Generative Justice}

\section{Artes textiles y Justicia Generativa}

\author{
Sarah Kuhn \\ University of Massachusetts Lowell \\ Sarah_Kuhn@UML.edu
}

\begin{abstract}
The fiber arts, because they are practiced in different forms around the globe, have the potential to teach us much about generative justice that unites labor, ecological, and expressive values. The ecological mutualism documented in Navajo corrals supports traditional weaving, dyeing, food, and medicinal practices in a sustainable and generative cycle that survives despite disruption and exploitation. The network of fiber craftspeople, retailers, ranchers, teachers, spinners, and dyers and their organizations supports the social mutualism of fiber communities. Fiber arts practices can benefit individuals, communities, the environment, and public health, among other things. Conscious fiber activism and critical making can also be used to explicitly draw attention to problems such as overconsumption, waste, industrial "fast fashion," labor exploitation, environmental degradation, toxic risks,
\end{abstract}


intolerance, and the devaluing of women and their work. Fiber arts have the potential to support environmental and social mutualism and catalyze a new aesthetic of long-term attachment to meaningful objects and communities, reinforcing the creation and conservation of expressive, ecological, and labor value.

\section{KeYWORDS}

Fiber activism; indigenous culture; making; mutualism; repair.

\section{Resumen}

El arte textil (Fiber Art), practicado en todo el mundo bajo diferentes formas, tiene un gran potencial para mostrar cómo la Justicia Generativa unifica el valor del trabajo, con el valor ecológico y el expresivo. El mutualismo ecológico de los corrales Navajos ha sido documentado como una forma sostenible de obtener tejidos, comida y prácticas medicinales, a través de un ciclo generativo que ha sobrevivido a la disrupción y explotación. La red de artesanas, vendedoras, rancheras, profesoras, tintoreras e hiladoras mantiene este mutualismo social en sus comunidades. Además, las prácticas del arte textil pueden benefician tanto a los individuos, como a las comunidades, al medio ambiente y a la salud pública. Por otra parte, el activismo textil consciente y la creación crítica pueden también ser usados para llamar la atención sobre problemas como el sobreconsumo, la basura, la "fast fashion" industrial, la explotación laboral, la degradación ambiental, los riesgos tóxicos, la intolerancia y la devaluación de la mujer y de su trabajo. El arte textil tiene el potencial de sostener este mutualismo social y ambiental, y catalizar una nueva estética de vínculos significativos y de largo plazo de las personas con los objetos y las comunidades, reforzando así la creación y conservación del valor laboral, ecológico y expresivo.

\section{Palabras clave}

Activismo textil; culturas indígenas; creación; mutualismo; reparación. 


\section{Contents}

1. Introduction

2. Cases

3. Discussion: Fiber Arts and Generative Justice

4. Conclusion

5. Referencias

\section{Contenidos}

1. Introducción

2. Casos

3. Discusión: el arte textil y la Justicia Generativa

4. Conclusión

5. Referencias 


\section{Acknowledgements}

The author would like to thank Ron Eglash and three anonymous reviewers, whose comments helped to significantly improve this paper. 


\section{Introduction}

Because the fiber arts are a culturally, ecologically, and historically ubiquitous human activity, they make a fascinating lens through which to examine issues of generative justice. They are often a literal intertwining of human and natural agency, and their crafting includes some of the most infamous cases of labor exploitation as well as some of the most profound cases of sustainable fusions between artisans, environments and communities. By examining several cases of fiber arts activities in their social, economic, and environmental contexts, we can see that fiber practices are good "things to think with" as we seek to understand the benefits of, and challenges to, generative justice ${ }^{1}$.

String made from grasses was one of the earliest human technologies, and textiles and garments made with twisted animal, vegetable, or synthetic fibers (that is, yarn) are with us more than ever-in everything from industrial "fast fashions" to advanced engineered composite materials, and in Do-It-Yourself home knitting, crocheting, quilting, and sewing. Clothing and textiles are ubiquitous objects of human expression and function, and yet fiber arts activities are under-studied by scholars of science and technology. One goal of this paper is to demonstrate that fiber and textile practices can be productive objects of study for understanding and promoting generative justice.

A second goal is to begin to examine some of the forces that draw fiber arts practices, in their culturally, economically, and ecologically situated contexts, either toward more generative or toward more extractive conditions. In this, I will use the language employed by Eglash and Garvey (2014), who take a systems approach to understanding generative justice. Using the notion of "basins of attraction," they are concerned with the states toward which complex systems are attracted. The dynamics of a complex system can tend to draw it toward a particular state or condition, and away from others. In a simple system, like a suspended pendulum, the weight is drawn toward a point directly below the point from which it is suspended. Complex systems generally have no such point, but they do have areas, or metaphorical "basins of attraction," toward which they are drawn, just as a river's water may flow into a literal basin. What conditions or situations cause a complex social, economic, and

\footnotetext{
${ }^{1}$ Claude Levi-Strauss (1962) argues convincingly for a "science of the concrete," and for the rationality of socalled "primitive" cultures, which can be observed in their interactions with the material and natural worlds. In a famous formulation, he tells us that, for example, traditional cultures' relationships with animals illustrate that these groups find them "bonnes à penser" or "good to think [with]."
} 
environmental system to move toward a generative state or "basin," and what might steer it toward a more extractive basin?

\section{Cases}

We can begin to ask these questions while looking at specific cases of situated fiber activities and some of the forces that move them toward and away from generative conditions.

\section{Case 1. Navajo weaving}

Traditional Native American Navajo (Diné, in their language) practices are an instructive case of the circulation of unalienated value-labor, ecological, and expressive-within a society. The Navajo Nation is located in a 25,000 square mile area covering parts of the states of Arizona, New Mexico, and Utah in the American Southwest. Elevations vary from 4,000 feet (1,250 meters) to 11,000 feet $(3,437$ meters) and from hot deserts to alpine meadows (Kuznar, 2001). After Spanish contact, the Navajo adopted pastoralism, raising sheep, goats, cattle, and horses. Although trading was common among indigenous groups in the Americas long before the arrival of Europeans, trade with non-indigenous groups expanded dramatically in the $19^{\text {th }}$ century with the arrival of the railroads and the establishment of trading posts, providing the Navajo with increased access to markets for goods such as blankets, mutton, wool, silver, and turquoise. However, "Navajo prosperity came to an abrupt halt during the 1930s when a federally implemented stock reduction program forcibly reduced Navajo livestock holdings by half and severely restricted the legal movement of people and animals across their lands" (Kuznar, 2001, p. 24). Today Navajo continue to own livestock and to graze them on tribal lands, in spite of the fact that wage work and government transfer payments (welfare) are their primary sources of income.

Traditional Navajo say "Sheep is Life," reflecting the importance of sheep in every facet of their culture. Sheep still provide a ready source of protein through their meat, a source of wool for clothing and blankets, a source of cultural pride and identity, and even ecosystem services that promote the development and propagation of important plants. Ethnobotanist Lawrence Kuznar describes a relationship that ecologists call "mutualism," a symbiotic relationship between species in which all partners benefit, in his analysis of the ecosystems surrounding Navajo corrals (2001). Unlike, for example, parasitism, in which one organism benefits at the expense of another, mutualism creates a cycle of value that perpetuates the relationships and allows the flourishing of diversity. Human/plant mutualism is a global 
phenomenon widely documented in traditional societies, and is important to subsistence and survival (Kuznar, 2001).

Navajo corrals are enclosures used seasonally for sheep and other livestock when they are not in pasture. Plants may occur in these corrals either because they were there when the corral was created (corrals are generally used for 5-10 years, then abandoned) or because the plants entered the corrals with the animals, generally as seeds either in their dung or clinging to their coats. These plants benefit from the disruption to the soil caused by animal hoofs and from human intervention (such as the work of preparing the corral for use) and from the animal dung and urine that fertilizes them.

Kuznar has identified twelve plants most prevalent in Navajo corrals. Eight of these are useful food plants, while three more have sacred medicinal uses (2001). Animals and humans may benefit from this source of food (older Navajo remember eating some of the plants as "starvation foods" during the 1930s) and from their health and cultural value as well. Animals benefit from the care given to them by humans, and the Navajo derive value from the wool and meat of their sheep, as well as from the indication of prosperity that a large flock provides.

Navajo weaving is part of this mutualism. Sheep provide wool to be spun into yarn and woven, and plants provide natural dyes that complement the varied natural shades of the wool. Navajo blankets and traditional woven dresses (biil) are both useful and expressive of cultural and clan identity. The activity of weaving is inseparable from the activity of sheep care, of connection to ancestors, of providing for family, and of spiritual observance.

Weaving also extends to the sheep. Sheep are part of the natural world. How the sheep are cared for plays an important part in weaving. Weaving also extends to the land. You take your livestock to a place where there is plenty of grass, plenty of water, and you care for them and talk to them. There are songs and rituals that involve the sheep, and they also extend to the land-to Mother Earth. Weaving is nothing without all these other elements.

(Walters, 1996, p. 31).

In her discussion of Navajo weaving, Bonar (1996) notes that the social ecology of weaving binds the creative act of fiber arts design with this biological and cultural network:

“... this art extends not only to a person's work, but to the way a person conducts his or her life. Songs and prayers reestablish a weaver's relationship with his or her art and, by association, with nature. The parts of the loom, the rug designs, and the colors all relate to 
elements in nature and also reflect male and female principles. When everything a weaver uses is in balance, harmony prevails"

(Bonar, 1996, p. 10).

The Navajo refer to this harmony as hozho, sometimes translated as "I will walk in the Beauty Way."

Like other traditional societies, the Navajo have over time changed and adapted to new opportunities-new materials and commodities arriving through trade, new designs and dyes from outside sources, new livestock breeds, to name just a few examples. Some outside forces, however, have disrupted the mutualism of traditional pastoral life. Commercial traders who introduced commercial dyes and sought Navajo blankets for pennies a pound; government officials who deemed the traditional churro sheep-the heirloom breed acquired from the Spanish-inferior and in need of eradication; U.S. tariffs on rug wool; and the transition to a cash economy on the reservation are among the many forces that have exerted negative pressures on Navajo weaving.

Today the masterworks of Navajo weavers sell for five-figure sums on the international art market, yet most Navajo weavers live in poverty ${ }^{2}$. Lack of access to markets means that much of the profit from the sale of contemporary Navajo blankets may go to middlemen. As the market for contemporary rugs has declined, the most sought-after Navajo weavings are antiques, often by artists no longer living, who in any case would not benefit directly from the appreciation in value of their work. As M'Closkey (2014) observes, “An object-based aesthetics grounded in Euro-western epistemology fuels connoisseurship, while ignoring the politico-economic relations of long term cross-cultural asymmetrical trade" (p. 2).

The generative foundations of Navajo fiber arts still offer possibilities for resistance and survival. Economic pressures would dictate that the Navajo should give up raising traditional churro sheep, whose wool is not in demand on the open market, and instead focus on a breed like Merino, whose wool is much softer and is considered more desirable. Choosing churro instead is an act of resistance to the political economy of "rationalization"; one could say it is rational from a generative perspective, because raising the heirloom churro and using its wool

\footnotetext{
2 I use the term "poverty" here to refer to lack of money. The concept of poverty is an important one to challenge in the context of generative justice, since the value circulated in generative systems may not be financial, or may not be solely financial. So-called impoverished communities may nevertheless have strong social ties, for example, and relatively affluent communities may exhibit symptoms of alienation or an absence of social capital. For some in the global capitalist system, money may not be the thing most missing in their lives.
} 
is fundamental to the circulation of cultural and ecological value, rather than the extraction of capital. D. Y. Begay, a Navajo weaver who has also lived on the U.S. East Coast and is married to an Anglo man, tells of learning weaving by watching her mother over the years. "My mother and grandmother always said, 'A woman has to weave.' To be a complete person, a Navajo woman should weave or have some knowledge of weaving. Weaving is important for your thinking. Weaving is communication. It is like speaking Navajo" (Begay, 1996, p. 17).

Support and solidarity from non-Navajo who value these traditions could help to bolster a generative system of Navajo weavers. When the Smithsonian Institution began commissioning inexpensive reproductions of famous American quilts from China for sale in their gift shops, American quilt enthusiasts protested the production of cheap knock-offs. Ultimately the protesters succeeded in persuading the Smithsonian, a government institution, to procure reproduction quilts from "two domestic cooperatives-Cabin Creek Quilters in Appalachia and Missouri Breaks in the Lakota Sioux [Indian] reservation.” (Quilt Study Center, n.d.) Although Native American designs-taken from Navajo rugs, Sioux tipi covers, Pueblo ceramics, and many other sources-are constant targets of cultural appropriation, non-Indians have generally not protested this uncompensated extraction of value. Increased public awareness and protest against cultural appropriation could help to protect native fiber arts from widespread extractive practices.

\section{Case 2. The Quilters of Gees Bend}

The celebrated quilts of Gees Bend, Alabama are also an interesting case of sustainable making with a prized aesthetic shaped by culture, oppression, and extreme scarcity. Gees Bend is a tiny town of African-American descendants of slaves who worked on the former Pettway plantation. Because of its isolation in the bend of a river, residents have had relatively little access to jobs, money income, and commodities-and indeed the settlement was declared one of the poorest places in America during the Great Depression. Although the community remains poor, Gees Bend quilts became a cause célèbre in the art world in the early 2000s, when a collection of Gees Bend quilts was shown at Houston, Boston, and New York art museums. Hailed as far more like the sophisticated modern art of the $20^{\text {th }}$ century than the fussy chintz patchwork of European settlers, the quilts featured bold colors and asymmetrical, likely African-inspired, improvisational fields and strips of color.

Although the story of the Gee's Bend quilters is often told as a story of an isolated, impoverished group of folk artists who were "discovered" by the New York art scene in the 
late $20^{\text {th }}$ century, the reality is much more complex. When Mark Pettway purchased the plantation at Gee's Bend and 101 slaves in 1845 from his Gee relatives, he forced at least an equal number of slaves he owned in North Carolina to walk to Wilcox County, where Gee's Bend is located. Of those remaining in Gee's Bend today, many are the descendants of these two groups of slaves. After the Civil War, the black residents became tenant farmers. Cotton farming became unsustainable after the stock market crash of 1929, when the price of cotton fell to pennies per pound. During the New Deal era, small loans came to Gee's Bend farmers in the mid-1930s, followed by a large scale intervention in which the government purchased nearly 7,500 acres from their white owner and resold plots of land to about 100 families, using low interest loans. The federal Resettlement Administration and its successor, the Farm Security Administration, had a policy of promoting cooperative enterprises, and created a cooperatively owned medical clinic, followed shortly thereafter by a farm cooperative, a community store, and other enterprises. Prosperity did increase in the community, and by 1942 there was surplus food that could be sold to the war effort. When congress abolished the Farm Security administration in 1946, however, much of the aid dried up. (Beardsley, 2002) At a time when large scale mechanized farming (supported by government funds and policy) were ascendant, the farmers of Gee's Bend were hard put to make money. Still, community cohesion and capacity had been further strengthened by experience with the cooperatives.

In February, 1965, a charismatic young preacher came to Pleasant Grove Baptist church and preached about voting rights for African Americans. Inspired by Dr. Martin Luther King, many crossed the river on the ferry to march and register to vote in Camden, Alabama. Some also joined him on the celebrated march from Selma to Montgomery, Alabama, on March 2125 of that year. Before long, the ferry was shut down by the authorities, threatened by black activism, further isolating Gee's Bend. In late 1965, an Episcopal priest from the Selma Interreligious Project, formed in the aftermath of the march and its attendant violence, saw some quilts hanging on a clothesline in Wilcox county. He not only admired them, but also recognized their unique qualities and their similarity to the "op art" popular in the New York art scene at the time. Working with sympathetic volunteers in New York, Father Walter and his collaborators organized two sales of Wilcox county quilts, many of which the makers had taken from beds in their homes. As the quilts became known in New York, prices rose (from $\$ 10$ each to $\$ 100$ !) and the women of Wilcox county proposed to establish a quiltmaking cooperative which they dubbed the "Freedom Quilting Bee." Orders from Bloomingdales, the upscale department store, followed, and supported the construction of a sewing center for coop members, but with the orders came a push for standardization in both design and 
stitching, which some of the women resented. Later, Sears Roebuck ordered corduroy pillowcases from the Freedom Quilting Bee, with a specific "coat of many colors" design (Beardsley, 2002; Callahan, 2008). The work became more like "mass craft" production than like the expressive, improvisatory bricolage of earlier years. Participants faced a choice between reaping money from their labor and creating expressive value.

During the periods when Gee's Bend quilts became desirable items on the art market, the sale of quilts brought more money, which could be used to purchase sewing machines and new fabric as well as household necessities, and even to pay college tuition for children in the community. Like the Navajo, however, whose antique blankets have seen substantial appreciation in value, the quilters of Gees Bend do not profit from the re-sale of older quilts. Further, part of the remarkable aesthetic of the Gees Bend quilts depended on scarcity: hand sewing of re-used fabrics, pieced in the lap into an irregular patterned top. Purchased material and machine sewing create a different look, less characteristically idiosyncratic (Personal communication, 2013).

As with the Navajo, fiber artists in Gee's Bend lived in a complex environment in which oppression and persecution, isolation, strong cultural traditions, the particularities of the physical environment, intermittent access to outside markets (and pressures from market forces)—combined with a state and local policy environment that could be beneficial, obstructive, and paternalistic-created tensions that at times pulled the artists toward a generative basin, and at other times pushed them toward an extractive basin.

\section{Case 3. Global Artisanal Production}

In the shadow of giant global corporate networks producing apparel and home goods for the mass market, there are alternative systems of production that offer at least the possibility of textile and fiber production systems that are less exploitative and more generative-of labor, ecological, and expressive values. Here are three brief examples, chosen from among many (see International Vendors in Case 4 for two more).

a) Garment production in India: The global textile and apparel industry employed 34.2 million people worldwide in 2014, and the global apparel market is valued at more than 3 trillion U.S. dollars. In the U. S. the fashion industry is estimated to employ 1.8 million, most of whom (79\%) work in retailing (Global Fashion Industry Statistics, n.d.). Labor exploitation and workplace hazards in the garment and textile industries have been well documented, although non-exploitative production is possible. One of the approaches to 
trying to create non-exploitative fashion production is the formation of cooperatives or small artisanal workshops supervised by founders committed to fair employment practices.

Marketplace India, founded in 1980 to assist three women in the slums of Mumbai, is one of the earliest members of the current cohort of small artisan cooperatives. It has grown, over the more than 35 years of its existence, into a network of over 400 artisans organized into 11 cooperatives. In addition to textile and garment design and production, this fair trade $^{3}$ nonprofit offers skill building and entrepreneurial opportunities to women, and academic support and awards for their children, all in aid of beneficial economic development for households and communities (http://www.marketplaceindia.com/). Other efforts like those of Marketplace exist, but they are all dwarfed by the behemoth of industrial production and the "fast fashion" industry.

b) Baskets and public health in Namibia: At a social level, fiber arts activities and the networks that support them can often form a sort of "social mutualism." DeMotts (2008) describes women's involvement in craft work in the Caprivi Region of northeastern Namibia. When crafters come together to market, to harvest reeds (the raw material for baskets), to teach other women and girls, and to discuss the operation of their network of markets, they are engaged in a traditional form of production that has roots in their history, and that builds and reinforces community ties. Economic development initiatives are key to environmental conservation efforts in the area because they provide sustainable livelihoods for residents, who might otherwise deplete local resources in their struggle to survive and to gain money income (necessary for medicines, school fees and uniforms, and so forth).

Because basket-making and other crafts are almost exclusively women's work, fiber artists' gatherings create a gendered space that has also become an opportunity for HIV/AIDS education and outreach in the part of Namibia with the highest infection rate. Conservation organizations have become involved in HIV/AIDS education, prevention, and care because the epidemic has caused staff deaths, illness, stress, and demoralization (DeMotts, 2008). The existing mutualistic system in which the fiber artists were engaged became an opportunity to add further value to the community through a women-oriented public health program. In this way, a system that starts with the purpose of creating labor and environmental value while preserving cultural craft practices also supports the physical health of community members.

c) From problem to opportunity in Nigeria: Nigerian-American computer scientist-turnedentrepreneur Achenyo Idachaba turned a serious economic and environmental problemthe dramatic overgrowth of the invasive plant water hyacinth-into an opportunity by

\footnotetext{
${ }^{3}$ Not all "fair trade" is created equal. Some organizations consider commodities grown on large plantations eligible for fair trade designation, while other stress the producer-centered, empowerment-focused production of producer cooperatives. In this article only examples of the latter are mentioned. See for example $<\mathrm{http}$ ///ssir.org/articles/entry/the_paradox_of_fair_trade>
} 
learning to harvest, dry, and weave water hyacinth fibers into export-ready craft products like baskets, storage bins, and trivets. Searching for a project more meaningful to her than her job in corporate America, Idachaba observed that because of the weedy overgrowth, "economic livelihoods have been hampered: fishing, marine transportation and trading; communities where fish yields have diminished; communities where schoolchildren are unable to go to school for days, sometimes weeks, on end." Her new enterprise, MitiMeth (http://www.mitimeth.com), created, in her words, a "win-win solution whereby the environment is taken care of by the weeds being cleared out of the way and then this being turned into an economic benefit for the communities whose lives are impacted the most by the infestation of the weed" (Idachaba, 2015). From an environmental problem, labor and environmental value are both created. Products are standardized in order to be offered for sale, and are mostly household objects of a sort primarily found in the developed world, such as coasters and key chains.

\section{Case 4: Fiber Hobbyists in the United States}

In spite of the commodification of clothing and fashion-perhaps partly in reaction to itthere exists in the U. S. a largely-unseen network of knitters, crocheters, sewers, and weavers. Almost all are hobbyists who derive no income (or certainly no net income) from their fiber activities. In 2012 there were 3.1 million people in the US participating in "needle arts" of various kinds. Spending by the most dedicated fiber arts enthusiasts totaled between $\$ 750$ and $\$ 900$ million in that year (National NeedleArts Association, 2013). Fiber enthusiasts come from all social classes, all races and all ages, and although most are female, some men are also fiber arts makers.

Viewed by non-participants as an archaic and low-skilled activity associated with grandmothers, knitting and crochet are nevertheless garnering interest from a younger Do-ItYourself generation, and are enjoying sustained interest from some older women. Fiber arts hobbyists are supported by and contribute to a network of enthusiasts nationally and globally. This network has many parts. In the United States, the most common are:

Independent yarn stores. Locally-owned shops sell yarn, tools, patterns, and sometimes also processed fleece (roving) for spinning into yarn. They often offer classes, and many have a seating area where fiber enthusiasts can drop in to knit or crochet. These stores build community and propagate skills and knowledge, as well as developing in fiber artists an aesthetic and sometimes a technical-scientific appreciation of fibers and fiber arts. To compete with chain stores and to cater to an knowledgeable clientele, these stores carry higher quality and specialty yarns, often including at least a small amount of locally produced yarn. These yarns cost more than mass produced yarns because of their quality and the cost of the raw material from which they are made. Owning and operating an 
independent yarn store-like owning an independent bookstore-is a labor of love, not a way to get rich. While such yarn stores operate on the margins economically, they often are at the center of fiber art's generative potential.

Mass retailers. "Big box" chain craft stores sell yarn, knitting needles, and crochet hooks, as well as other fiber arts supplies. They carry low cost synthetic yarns, although wool and cotton yarns are also available. Generally no instruction or additional information about the product is available, although mass producers of yarn may have their own company web sites that provide information and online instruction (see for example http://www.lionbrand.com/). We might view their role as similar to that of large scale chip manufacturers in Eglash's account of open source hardware (see introduction to this special issue): while its mass production is not itself generative, it supplies many small institutions which are.

Guilds. These are essentially clubs of fiber enthusiasts; their use the archaic term "guild" paradoxically reflects a humorous self-awareness of their defiance of contemporary consumerism, while simultaneously giving it a vocational dignity that is not implied by a term like "club" or "hobby." Many guilds highlight a particular expertise, for example spinning and quilting guilds, and some have formal programs at their periodic meetings, in which an invited speaker makes a presentation or teaches a workshop. Guild membership is typically inexpensive and the activities are primarily the holding of regular gatherings, which offer a chance to bring fiber work and socialize with others who share an interest in fiber activities, techniques, tools, and sources of materials.

Farmers and ranchers. Sheep provide the most common animal fiber used by knitters, crocheters, and weavers. There are many varieties of sheep, and their wools are known for their different performance characteristics-durability, softness, lightness, sheen, ease of spinning, and so forth. Goats, alpacas, rabbits, and even domestic cats and dogs have been used by artisans as sources of fiber to spin or felt (make a nonwoven textile by matting fibers together). For those who can afford them, even more precious and exotic animal fibers, like cashmere, vicuña, and Qiviut (the delicate under-coat of the Arctic muskox) are available. Small farms may supply the fiber needs of a small group or a single independent yarn store, while larger operations may buy equipment for processing or send wool to a specialty mill to be spun. For some fiber enthusiasts, developing a relationship with a farmer and purchasing locally grown fibers is an important part of the experience. The term "fiber shed," analogous to the watershed that is a region's source of water, has been coined to refer to the region in which a fiber artist works and from which locallysourced fiber comes.

Conferences, workshops, schools, and retreats. Educational opportunities for fiber artists to improve their skills take many forms. Some of the formal opportunities, which offer feebased workshops and classes, are annual fiber conferences (Machine Quilting Expo, Stitches East and West, Vogue Knitting LIVE, and scores of others), the offerings of seasonal and year-round craft schools, fiber camps and retreats, and local adult education 
providers. Children in Waldorf schools learn to knit at an early age. Online classes are increasingly available, too, and their quality has improved significantly in recent years.

Farmers' markets and festivals. Yarn and unspun fleece, as well as finished goods such as knitted, crocheted, woven, or felted apparel, are often available at larger and more upscale farmer's markets, and many states also hold annual fiber festivals in addition to the annual state agricultural fairs that are a staple of rural life. These festivals often include classes, and the vendors' booths are an opportunity to purchase yarn direct from the farmer.

Online communities. The free web site Ravelry, devoted to knitting and crochet, has more than 4.2 million registered users worldwide. Members form interest groups, sell and share patterns and yarn, seek and give advice, learn new techniques, and catalogue their yarn inventory ("stash"). Etsy, a better-known operation which got its start as a place for users to sell their handmade wares, is far more heterogeneous but also a home for fiber artists, and many use other social media such as Facebook and Instagram as well.

International vendors. Shoppers at specialty yarn stores are likely to encounter yarns from around the world. Some are the result of economic development efforts that aim to create markets and support sustainable livelihoods among the rural poor in developing nations. For example, Manos del Uruguay is a group of cooperatives that produce beautiful fair trade certified yarns whose sale supports farmers and artisans in Fraile Muerto, Rio Branco, and Dragón, Uruguay. Linda Cortright, editor and publisher of Wild Fibers magazine, became so enamored of the resilient herders she met in India's High Himalayas that she raised money to open the Cashmere Center there, so that spinners and artisans from the community could have a sheltered place to produce yarn and other cashmere products year round. Wild Fibers' first lot of 150 skeins of hand spun cashmere sold out immediately to the magazine's readers, despite the premium price. For many fiber artists, the source and story behind the yarn is part of the allure and gives additional meaning to their handmade goods.

Friends and family. Perhaps most important, friends and family often serve as teachers, resources, and supporters for fiber enthusiasts. If you ask a knitter or crocheter who first taught them, the most common answer is "my grandmother." Both boys and girls often learn from their grandmothers, at least in an earlier era when grandma was less likely to be in the paid labor force. It is rare to meet a knitter or crocheter, even a stranger, who will not readily offer to help with a problem or give a quick lesson in technique. Knitting in public is a quick and easy way to strike up conversations with passers-by, and travelers who make their way to an independent yarn store in an unfamiliar place often find a welcome. 


\subsubsection{Discussion of Case 4 Networks}

In what ways do fiber hobbyists' creative activities, situated within this network, generate and circulate value? The answers are many. To begin with the individual, there are psychological benefits to engaging in knitting, sewing, and other needle arts. Most knitters report that these activities have a relaxing and calming effect. Although almost no research has been conducted on this topic, preliminary evidence suggests that rhythmic manual activities with a relatively low cognitive load can be calming and can aid attention (Corkhill, 2008; Andrade, 2010 reports similar effects for doodling). Engaging in creative work can itself be deeply satisfying, and wearing something one has created from a simple piece of string can be meaningful as well. Because there are many opportunities for fiber enthusiasts to come together in groups, working on individual projects while they chat and sometimes provide tips, participants can also derive individual benefit from "parallel play" (Parten, 1933) in which participants play (create) adjacent to one another, perhaps showing occasional interest in each others work but with the primary focus on ones own creative activity.

Much fiber arts activity is economically irrational; it is the rare fiber enthusiast in highcost areas like the U.S. who can sell their wares for much more than the cost of the materials, and in any case the most ardent makers typically give away much of what they produce (because they want to; and after all, how many scarves and sweaters can a person wear anyway?) Knitting, crochet, and quilting for charity are common activities, engaged in both by organized groups and by individuals. For 20 years, fiber artists have been donating blankets and afghans to Project Linus, which gives them to children in need. The Red Scarf Project collects red scarves created by the public and gives them on Valentine's Day to youth who are moving from the foster care system to college. Knots of Love distributes donated hand-knit hats to cancer patients, and tiny blankets to babies in incubators. Others knit and crochet for soldiers, the homeless, and many other causes.

Fiber arts enthusiasts often create ecological value along with expressive and labor value. The origins of pro-sustainability fiber work can be found in traditional societies and in the work of the rural and urban poor - a fact particularly highlighted in the cases of Navajo weavers and Gee's Bend quilters. Because of their value and scarcity, textiles were often reused and re-purposed, in line with the traditional expression of New England frugality, "Use it up. Wear it out. Make it do, or do without." Children's clothing was often made from the worn 
out clothing of adults, and younger siblings wore the outgrown clothing of their older sisters or brothers. Clothing and housewares might be made from the feedbags in which animal fodder arrived on the farm. Economic constraints could generate expressive beauty, however, in addition to important use value. Patchwork quilts, still treasured heirlooms in some families and of increasing value in the art market, were ways of re-using still-useful fabric from which the worn-out parts had been cut away. Although slapdash workmanship would have made a homely quilt of equal warmth, quilters often took great pains to make designs in patterns that honored tradition, harmonized color, and pleased the eye. Often the work of sewing the pieced quilt top onto the layers that form the stuffing and underside of the quilt would be performed as a community activity at a "quilting bee" where multiple quilters would work together to finish a single quilt. A time consuming process that was manually but not mentally demanding - thus allowing conversation - the quilting bee served to build community among women quilters and reinforce mutualism, in which all helped all.

\section{Case 5. Political Expression through fiber activism}

Finally, fiber artists and consumers create and circulate expressive value through social and political critique with fiber as the vehicle. Resistance to economic, political, and social regimes can be expressed either explicitly or implicitly, and participation is not limited to those with the skills to create fiber artifacts.

a) Protesting Fast Fashion: Activist consumers who are not fiber makers can still use textile and fashion consumption-or its avoidance-to create expressive value. Buying ethically sourced garments, textiles, and other products can be an explicitly political act of protest against labor exploitation, as can participating in social action such as "Fashion Revolution," an organization founded after the devastating collapse of the Rana Plaza complex in Dhaka, Bangladesh, in April 2013 that killed 1,134 people and wounded 2,500 others. Fashion Revolution, which now has participants in more than 80 countries, encourages consumers to ask "Who Made My Clothes?" and particularly to address this question to clothing brands around the world. (http://fashionrevolution.org/) Buying clothing and housewares made from natural, sustainably produced fibers and textiles avoids petroleum-based materials and the toxic chemicals usually used in plant fiber production and processing. While some consumers purchase natural materials only for aesthetic or health reasons, many also value the pro-sustainability message such a purchase can send.

Activities such as "Buy Nothing Day" are acts of protest against hyper-consumption in the developed world. Sheena Matheiken conceived the Uniform Project, for which she wore the same "little black dress" every day for a year, accessorized with things she already 
owned or with donated items. Partly an exercise in sustainability, partly a fund-raiser for a foundation supporting children in the slums of India, the Uniform Project garnered worldwide attention and led to many actions inspired by Matheiken's work. Year 2 of the Uniform Project saw a series of hip and interesting young women wearing a customdesigned black dress daily for a month, with proceeds to charity. A pattern for a little black dress can be found on the project's web site so that supporters can make their own (http://www.theuniformproject.com/).

b) Political messaging: Like the little black dress, fiber arts can play a semiotic function by accompanying or expressing explicitly political messages. "Yarn bombing" (a nonviolent activity despite its name) is the act of placing knitted or crocheted items on public structures. A form of street art begun in the mid-2000s, yarn bombing can be simply decorative or can convey a social, political, or environmental message. A pink patchwork coverlet is custom-fit to cover a military tank in Copenhagen; artist Agata Oleksiak covered the large statue of a charging bull on Wall Street in New York with a pink and purple yarn cozy; and knitter Magda Sayeg has covered busses and pillars, but also guns (Wollan, 2011). Unlike hastily painted signs or angry outbursts, the patient labor required to do yarn bombing conveys the commitment of protesters to careful, reflective thought and action in what Haraway calls a "material-semiotic hybrid" (1997, p. 129).

Around the world, fiber artists are finding their voices through public, activist making. "Knitters for tolerance" knitted and wore yarn beards in support of bearded drag performer Conchita Wurst, winner of Eurovision's 2014 song contest. At a time when gender conformity is highly contested, they showed their solidarity with a talented performer who with evening gown, (real) beard, and a beautiful voice, was smashing gender norms. By contrast, three women from a group calling themselves the "Knitting Nanas"-embracing gendered identity for political purposes-were arrested in January 2016 while protesting against the potential environmental damage caused by coal-seam gas wells in New South Wales, Australia. They adopted the group's moniker as a way of expressing the group's commitment to maternal nurturing as a source of activism (Knitting Nannas charged in NSW coal-seam gas protest, 2016).

c) Environmental messaging: The "Crocheted Coral Reef" is a crowd-sourced art installation designed to draw attention to the perils facing the world's oceans and reefs. Inspired by Taimina's (2009) engaging and beautiful crocheted hyperbolic planes (mathematical models of an object in non-Euclidean geometry), the Los Angeles-based Institute for Figuring created the reef using crowd-sourced fiber art inspired by the leafy, coral-like appearance of crocheted hyperbolic planes (http://www.theiff.org/). The "fuzzy" familiarity and approachability of fiber arts can make science topics less intimidating and more relatable for the general public. Indeed, Taimina's work on hyperbolic crochet holds the potential to inspire new approaches to STEM (science, technology, engineering, and math) education (http://thinkingwiththings.com/). 


\subsubsection{Discussion of Case 5 Networks}

Fiber arts activists are engaged in what Ratto (2011) calls "critical making." This sort of activism, which can take place in the digital as well as the material sphere, “...provides both the possibility to intervene substantively in systems of authority and power and...offers an important site for reflecting on how such power is constituted by infrastructures, institutions, communities, and practices." (Ratto \& Boler, 2014, p. 1) Critical makers can be seen as a small subculture in the overall trend toward DIY (Do-It-Yourself), but Ratto and Boler point out that critical making might better be thought of as DIT (Do-It-Together) or DIO (Do-ItOurselves), stressing the collective, community- and citizenship-building nature of critical making (Ratto \& Boler, 2014) ${ }^{4}$.

\section{Case 6: Repair}

In the age of technologies with "no user-serviceable parts inside," proud hackers are disassembling and remaking electrical goods, and volunteer-run "fix-it" spaces are popping up across the U.S., from the Repair Café in Bellingham, Washington to the Senior Center in Lexington, Massachusetts. The Bellingham Repair Café's web site says explicitly that its goals are environmental (keep broken items out of the waste stream and extending their life), community service (save money for community members), social (gathering to repair is fun and builds community) and educational (repair volunteers will explain what they are doing to interested people; http://bellinghamrepaircafe.net/)

a) In the world of fibers, repair is enacted through the ancient art of textile mending. In today's marketplace of cheap, disposable "fast fashion," most people don't know how to mend garments, nor would it be economically rational to use one's time to patch a garment that can be replaced for $\$ 19.99$. Socks are particularly cheap, and get a lot of wear in some spots, yet many knitters still knit socks. When a fiber enthusiast wears a button that reads "Yes, I know I can buy socks for \$2 at Wal-Mart!" it expresses not just a love of knitting but also a critique of cheap goods bought from international corporations. Hand knit socks, unlike their mass-produced counterparts, are well worth mending. They also are an embodiment of expressive value, demonstrating the worth of unique hand work,

\footnotetext{
${ }^{4}$ A related but less analytically fruitful term is craftivism, which Greer defines as "The practice of engaged creativity, especially regarding political or social causes. By using their creative energy to help make the world a better place, craftivists help bring about positive change via personalized activism.” (2007 n.p.).
} 
quality materials, and gift giving or self-care. While mending has rarely been practiced as an explicit critique of cheap goods and hyper-consumption, it holds great potential as a critical practice that combines labor, ecological, and expressive value.

b) Buddhist perspectives: Japanese cultural traditions bring us particularly provocative examples of the meaning and value of mending. "Wabi-sabi" is a Japanese aesthetic, derived from Buddhism, which embraces impermanence and imperfection. "Kintsugi," or "golden joinery," is the art of mending broken ceramics with seams of gold resin, creating a new piece that overlays the original form with a spider web of gold, highlighting the places where the ceramic cracked (Gopnik, 2009). Kwan (2012, p. 7) describes the wabisabi aesthetic as one that "...values the marks on objects left by aging. [The Japanese] believe that everything has its story and we should work hard to preserve it rather than removing it." The cracks in a vessel are part of its story, and the repairs highlight, rather than conceal, the story, and the mending itself becomes part of the story as well. Boro textiles from Japan have been repeatedly mended over time, by peasants so poor that new clothing was a rarity. Boro garments and textiles often have patches on their patches; indeed the whole garment may consist of unmatched and asymmetrical patches, in which the wabi-sabi ethos finds great beauty. Modern boro can be done by fiber enthusiasts who are drawn to the technique in part because of its expression of care for the environment through the avoidance of waste.

\subsubsection{Discussion of Case 6 Networks}

In an economy dominated by cheap mass-produced goods, the objects in our lives have impoverished stories. "I bought it at Target" can't compare to "my late grandmother made this for me when I was a teenager" or "I found this at a tiny hole-in-the-wall thrift shop when I was hiking in Wyoming during a great spring break trip." The wabi-sabi aesthetic is generally missing in the English-speaking world; the appeal of patched denim jeans may come the closest. Ironically, however, the wear and patching of jeans too has become commodifiedjeans can be purchased pre-patched and already looking worn. It is possible, however, that Do-It-Yourself and sustainability movements are having an impact. In 2016, for example, Gawthorpe Hall in Lancashire, UK, home to the Gawthorpe Textiles Collection, mounted a show of visibly repaired textiles, inspired by the building renovation just completed. The Uniform Project and other interventions help lead the way.

Chapman (2015) sees waste and the disposal of cheap goods as a sign of a failed relationship between a person and an object, and argues that both the user and the designer can take responsibility for making a better, more long lasting relationship. He has coined the phrase "emotionally durable design" to indicate a new design goal: objects that encourage the 
formation of a long-term relationship. These can be manufactured objects created by professional designers, but they can also be objects whose significance comes in part from being handmade, either by oneself or by a known producer. If we make a scarf, a basket, a table, a pair of socks ourselves, or receive these from someone we know, the object has a story from the very beginning, and can go on to acquire an even richer meaning with use. A life with objects with which we have a good relationship is also life with less waste, and the possession of and care for these objects thus creates and perpetuates ecological and expressive value.

In the same way that wabi-sabi develops in us an appreciation for the beauty of objects with a history of wear-and-tear, it is possible to appreciate the creative potential of constraints, including environmental and economic constraints. When Americans think of what it will take to protect our environment and our planet, the focus is usually on deprivation and doing-without. No iPods? No long road trips in cars? No long showers? Yet constraints can also be generative. The old saw that "necessity is the mother of invention" is confirmed by statements from leading innovators. Composer Igor Stravinsky wrote that "my freedom will be so much the greater and more meaningful the more narrowly I limit my field of action and the more I surround myself with obstacles.....The more constraints one imposes, the more one frees ones self of the chains that shackle the spirit" (1970, p. 49). Mid-century modern designer Charles Eames recognized and embraced constraints. "Design depends largely on constraints," he said, and key to design success is the designer's “...willingness and enthusiasm for working within these constraints" (Demetrios, 2001, p. 168).

This is not to celebrate deprivation or, more particularly, the dramatic inequalities in income and wealth both within the U.S. and around the world. The point of generative justice is not to make us complacent in the face of injustice-quite the contrary. But fiber artists and other makers, by choosing to spend their time and labor on creating and circulating expressive and ecological value, demonstrate that "the search for meaning in a throwaway world" (Frauenfelder, 2010) is not to be found in a paycheck. Some Millenials, graduating from college into the depths of the 2008 economic meltdown, addressed their employment challenges through entrepreneurship and a return to fundamentals: growing vibrant crops, creating specialty food products, running food trucks, designing and producing fashion accessories, and other ventures. What the long-term impact on their livelihoods will be remains to be seen, but these are creative and community-building responses to economic hardship. 


\section{Discussion: Fiber Arts and Generative Justice}

Many of the cases in which fiber arts groups succeed in creating a "basin of mutualism" rather than extraction are marked by the kinds of phenomena we saw in French sociologist Marcel Mauss' classic account of gift economies, The Gift (1954/2011). This study of gift giving in indigenous societies describes systems of exchange and reciprocity that predate a mercantile economy, and that function on many levels, only one of which is strictly utilitarian. Indeed, Mauss calls them "total social phenomena" that are "at once legal, economic, religious, aesthetic..." (p. 76). These exchanges happen between groups, not individuals, and serve to create, reinforce, or alter relationships between groups. These exchanges are "not exclusively goods and wealth...[but] rather courtesies, entertainments, ritual, military assistance, women, children, dances, and feasts; and fairs in which the market is but one element and the circulation of wealth but one part of a wide and enduring contract" (p. 3). Shows of wealth and generosity establish hierarchy, but in the context of mutual obligation. Both the inferior and the superior have obligations to one another, and to the society, based on their position.

In Mauss' view, these systems are fundamental to stability and to a moral society. Looking at the world from Post-World War I France (The Gift first appeared in French in 1925) Mauss saw intergroup conflict and a capitalist economy characterized by the pursuit of individual self-interest. He sought a return to the mutualism of a previous era, not entirely gone but often eclipsed, through "...the joy of giving in public, the delight in generous artistic expenditure, the pleasure of hospitality in the public or private feast. Social insurance, solicitude in mutuality or co-operation," he wrote, "...are better than the mere personal security guaranteed by the nobleman to his tenant, better than the mean life afforded by the daily wage handed out by managements, and better even than the uncertainty of capitalist savings" (Mauss, 2011, p. 67). "The mere pursuit of individual ends is harmful to the ends and peace of the whole, to the rhythm of its work and pleasures, and hence in the end to the individual" (Mauss, 2011, p. 75).

The community of fiber artists, when existing in a basin of mutualism rather than extraction, is a complex system of the sort Mauss describes, with economic, social, spiritual, ritual, and cultural dimensions. As a result, it can be difficult to separate out different forms of value created within these systems. As Table 1 shows, many of the cases discussed above exhibit labor, ecological, and expressive value creation, often in a complex web that demonstrates how intertwined these three dimensions of value can be. Nevertheless, it is 
worth asking what patterns emerge from examination of these sample cases, and what forces move fiber practices in more generative or more extractive directions.

Table 1. Cases And Values

\begin{tabular}{|c|c|c|c|}
\hline Case & Values* & Basin of Mutualism & Basin of Extraction \\
\hline Navajo Weaving & L, Ec, Ex & $\begin{array}{l}\text { Tradition, mutualism, scarcity; } \\
\text { Black Mesa and other weavers } \\
\text { groups. }\end{array}$ & $\begin{array}{l}\text { Trading posts, commodification, } \\
\text { chemical dyes, Federal sheep policy. }\end{array}$ \\
\hline Gees Bend Quilts & L, Ec, Ex & $\begin{array}{l}\text { Tradition, mutualism, scarcity; } \\
\text { Freedom Quilting Bee and the } \\
\text { Civil Rights movement. }\end{array}$ & $\begin{array}{l}\text { Pressures to commodify in order to } \\
\text { expand markets. Threatened by } \\
\text { rising incomes. }\end{array}$ \\
\hline Marketplace India & L, Ex & $\begin{array}{l}\text { Organization's founding } \\
\text { commitment to improving lives. }\end{array}$ & $\begin{array}{l}\text { Change in philosophy and } \\
\text { leadership. }\end{array}$ \\
\hline Namibian Baskets & L, Ec, Ex & $\begin{array}{l}\text { Artisan-led, collective governance, } \\
\text { traditional art with natural } \\
\text { materials. }\end{array}$ & $\begin{array}{l}\text { Pressures to commodify in order to } \\
\text { gain market access. }\end{array}$ \\
\hline $\begin{array}{l}\text { Nigerian Water } \\
\text { Hyacinth }\end{array}$ & L, Ec, Ex & $\begin{array}{l}\text { Labor and ecological benefits are } \\
\text { strong drivers; passionate leader. }\end{array}$ & $\begin{array}{l}\text { Pressures to commodify in order to } \\
\text { gain market access. }\end{array}$ \\
\hline Fiber Hobbyists & Ex $(L, E c)$ & $\begin{array}{l}\text { Independent stores, farmers, } \\
\text { workshops, gift ethos. }\end{array}$ & $\begin{array}{l}\text { Big box retailers, mass produced \& } \\
\text { synthetic yarns, commodification. }\end{array}$ \\
\hline $\begin{array}{l}\text { Fast Fashion } \\
\text { Activism }\end{array}$ & Ec, Ex & $\begin{array}{l}\text { Anti-consumerism and } \\
\text { sustainability movements. }\end{array}$ & Industrial Fast Fashion. \\
\hline $\begin{array}{l}\text { Crowdsourced } \\
\text { Activism }\end{array}$ & Ec, Ex & $\begin{array}{l}\text { Public enthusiasm, fiber skills, and } \\
\text { social media. }\end{array}$ & $\begin{array}{l}\text { Lack of fiber skills, time and } \\
\text { resource pressures among public. }\end{array}$ \\
\hline Japanese Mending & L, Ec, Ex & $\begin{array}{l}\text { Buddhist philosophy and aesthetic, } \\
\text { tradition, quality materials. }\end{array}$ & $\begin{array}{l}\text { Pro-consumption aesthetic favoring } \\
\text { novelty, obsolescence, and designer } \\
\text { goods. }\end{array}$ \\
\hline
\end{tabular}

Notes: * L=labor, Ec=ecological, Ex=expressive.

Source: Own production.

In her popular account of social entrepreneurship, The Blue Sweater, Jacqueline Novogratz (2013) describes the misguided attempts to arbitrarily place fiber arts entrepreneurship where it does not belong: "Women would be encouraged to make crafts though there was no market for them, and so we'd visit homes piled to the ceilings with unsold sisal baskets" (p. 87). Even 
when the ecological value for producing sisal, and cultural capital of weaving techniques is present, the idea that fiber arts can be inserted into an economy the way a McDonald's franchise can be arbitrarily inserted into an urban commercial district illuminates the error underlying such assumptions, and highlights the achievement that successful basins of mutualism represent. First, strong cultural commitments binding these practices with the ecological and expressive forms of value are crucial; not only in making them commercially viable but also resisting extraction. Some Navajo continue to raise Churro sheep despite the significantly lower commercial value of their wool. Many Gee's Bend quilters resisted the transformation from one-of-a-kind expressive quilts to more standardized production for the mass market, even though it meant forgoing much-needed cash. The deadly experience of colonization for the Navajo, and of slavery for African Americans, make the continuation of their fiber arts practices not just resistance to labor value extraction, but triumphs of survival against genocidal forces.

On the other hand, some of the most striking cases of generative justice in fiber arts occur for productive configurations that are entirely new. The Nigerian Water Hyacinth case involved locating a new fiber source. The Crocheted Coral Reef brought together hyperbolic geometry and environmental activism. Fast fashion opponents who are also concerned with the environmental impact of the fashion industry, as well as groups such as Marketplace have begun to innovate with new vegetable dyes and new ways of using scrap fabric. And like the Navajo and Gees Bend cases, they too have to stave off threats to value creation: there is always the possibility of some larger business taking over their niche; the potential loss of interest among consumers if they stay true to original values; and so on. To say that the most successful or impactful basins of mutualism are those with traditional or ancient ties is simply not accurate.

One way to address this observation is to blur the lines between the two categories of traditional and contemporary innovation: Navajo weaving has always involved innovation (the churro sheep were imported from Spain); and contemporary fiber arts innovations always draw from some aspect of tradition. But even acknowledging those fuzzy boundaries, the distinction needs to be made. If not, there is no basis for critiques of extraction such as the Smithsonian's use of Chinese-made quilts to substitute for domestic originals. And no basis for understanding why innovations would fail in the sisal basket case reported by Novogratz but succeed for the Nigerian Water Hyacinth or Crocheted Coral Reef. 
A better way to understand this distinction is to think about the innovation as an additional generative value. Consider, for example, what happens when a software developer puts her code into an open source commons: the value that might have otherwise been alienated and extracted by a private corporation has become "democratized." There is a hybrid combining the elite knowledge of coding with the "low entry barriers" of the commons. Similarly, when Taimina (2009) first created her crocheted hyperbolic planes, she was creating a hybrid form which combined her elite knowledge as a mathematics professor with the "low entry barriers" of crochet. She "open sourced" her mathematics, not in the sense of making it legally accessible to non-owners of IP, but in the sense of making it physio-cognitively accessible to "non-owners" of mathematics. The kinds of success we see in certain non-traditional basins of mutualism-even the ephemeral cases such as "yarn bombing" events for political activismcome about because fiber arts innovation can offer new circulatory paths for unalienated value; a kind of iatrogenic shunt for the body politic that allows new forms of value to aid our social health and wellbeing.

\section{Conclusion}

This article has had two goals, mentioned in the introduction. The first was to demonstrate that fiber arts have a powerful potential to partake in systems of generative justice. American readers are likely familiar with attempts to create more generative food systems by supporting farmers' markets, "eat local" and "slow food" initiatives, and urban gardening. Like the food system, there is a textile and fashion system that can be exploitative, but can also support vibrant mutualism in communities. Like the food system, the fiber system includes plants, animals, climate, culture, well-being, and both alienated and un-alienated forms of labor and exchange.

The second goal of this article was to begin to tease out, in particular situations, some of the forces that draw a fiber system toward a "basin" of mutualism or, on the contrary, toward extraction and alienation. These forces are complex and can be paradoxical. For example, isolation and scarcity can tend to promote mutualism, yet also deprive communities of resources and options. Extractive situations, while they are exploitative, may at times be a point of access to the global economy, which can provide opportunity for some. At a time when many relatively well-off young people in the U.S. are saddled with debt, worried about the environment and climate crisis, and seeking more meaningful opportunities than those handed to them by mainstream commercial culture, they can drawn to more mutualistic, local, 
artisanal approaches to food and fashion. Fiber arts activities create artifacts AND relationships. By creating an artifact that has value in the making (calming, creativity, parallel play) and in the giving (use value, social bonding, the emotional and cultural meaning of the handmade) they partake of and create labor, environmental, and expressive value through mutualism and within a network of humans, animals, and organizations. This can be a powerful "basin of attraction" for those dissatisfied with what the economic mainstream has on offer.

Advocates for health, sustainability, and social justice in food systems set an example for "slow fashion" and "buy local" textile and fiber arts movements, and can share strategies and tactics in the ongoing battle against labor exploitation in farming and in clothing production. A social movement in support of the creation and sharing of unalienated value in the fiber system can build naturally upon existing networks and practices, and can be the catalyst for a new, sustainable and anti-waste aesthetic that is the foundation of an economy that circulates meaning as well as money, in which stories are as valuable as salaries. 


\section{References}

Andrade, J. (2010). What Does Doodling Do? Applied Cognitive Psychology 24, 100-106.

Beardsley, J. (2002). River Island. In J. Beardsley, The Quilts of Gee's Bend. Tinwood Books.

Begay, D. Y. (1996). Shi' Sha' Hane' (My Story). In E. H. Bonar (Ed.), Woven by the Grandmothers: Nineteenth-Century Navajo Textiles from the National Museum of the American Indian. Smithsonian Institution Press.

Bellingham Repair Café (n.d). Retrieved from $<$ http://bellinghamrepaircafe.net/>.

Bonar, E. H. (1996). Woven by the Grandmothers: Nineteenth-Century Navajo Textiles from the National Museum of the American Indian. Smithsonian Institution Press.

Callahan, N. (2008) Freedom Quilting Bee. Encyclopedia of Alabama. Retrieved from $<$ http://www.encyclopediaofalabama.org/article/h-1628>.

Chapman, J. (2015). Emotionally durable design: objects, experiences and empathy. Routledge.

Corkhill, B. (2008). Stitchlinks--Guide to our Theories So Far. Retrieved from $<$ http://www.stitchlinks.com/pdfsNewSite/research/Our\%20theories\%20so\%20far\%20New_ $\%$ 20unshuffled\%20watermarked_4.pdf $>$.

Demetrios, E. (2001). An Eames Primer. Thames \& Hudson.

DeMotTs, R. (2008). Mitigating an elephantine epidemic: gendered space for HIV/AIDS outreach through Namibian conservancies. Population and Environment, 29(3-5), 186-203.

GLOBAL FASHION INDUSTRY STATISTICS. (n.d.). Retrieved from $<$ https://fashionunited.com/global-fashion-industry-statistics $>$.

Eglash, R., \& Garvey, C. (2014). Basins of attraction for generative justice. In Chaos Theory in Politics (pp. 75-88). Germany: Springer Science.

Frauenfelder, M. (2010). Made by Hand: Searching for Meaning in a Throwaway World. Penguin Group.

GopNIK, B. (2009, March 3.). At Freer, Aesthetic is Simply Smashing. The Washington Post.

Greer, B. (2007). Craftivism. In G. L. Anderson \& K. G. Herr (Eds.), Encyclopedia of activism and social justice. New York, NY: Sage Publications. (Quoted on Greer's web site at $<$ http://craftivism.com/definition/>) . 
Knitting Nannas charged in NSW coal-seam gas protest. (2016, January 17). The Guardian. Retrieved from

$<$ http://www.theguardian.com/environment/2016/jan/18/knitting-nannas-charged-in-nswcoal-seam-gas-protest>.

Haraway, D. J. (1997). Modest-Witness@ Second-Millennium. FemaleMan-Meets-OncoMouse: Feminism and Technoscience. Psychology Press.

IDACHABA, A. (2015) TED talk. Retrieved from <www.ted.com/talks/achenyo_idachaba_how_i_turned_a_deadly_plant_into_a_thriving_busin ess $>$.

Kwan, P. Y. (2012). Exploring Japanese Art and Aesthetic as Inspiration for Emotionally Durable Design. Paper presented at DesignEd Asia. Retrieved from $<$ http://www.designedasia.com/2012/Full_Papers/Exploring\%20Japanese\%20Art\%20and $\%$ 20Aesthetic.pdf $>$.

Levi-Strauss, C. (1962). The Savage Mind. Chicago: University of Chicago.

M'Closkey, K. A. (2014). Navajo (Diné) Weavers and Globalization: Critiquing the Silences. Textile Society of America Symposium Proceedings. Retrieved from $<$ http://digitalcommons.unl.edu/tsaconf/904/>.

Mauss, M. (1954/2011). The Gift: Forms and Functions of Exchange in Archaic Societies. Martino Publishing.

National NeedleArts Association. (2013). The State of Specialty NeedleArts. Retrieved from $<$ http://c.ymcdn.com/sites/www.tnna.org/resource/collection/386A6007-6C3F-4D15-A8646D0DBD47FB40/TNNA-2013-Market-Summary-Final.pdf>.

Novogratz, J. (2013). The Blue Sweater. New York, NY: HarperCollins Publishers.

Parten, M. B. (1933) Social Play among Preschool Children. The Journal of Abnormal and Social Psychology 28(2), 136-47.

Quilt Study Center. (n.d.) The Smithsonian Quilt Controversy. Retrieved from $<$ http://worldquilts.quiltstudy.org/americanstory/identity/smithsoniancontroversy $>$.

Ratтo, M. (2011). Critical making: Conceptual and material studies in technology and social life. The Information Society, 27(4), 252-260.

Ratto, M., \& Boler, M. (2014). DIY citizenship: Critical making and social media. Cambridge, MA: MIT Press. 
StravinSky, I. (1970) Poetics of Music. Harvard: Harvard University Press. (original edition 1942).

Taimina, D. (2009). Crocheting Adventures with Hyperbolic Planes. A K Peters/CRC Press.

Walters, H. (1996). The Navajo Concept of Art. In Bonar, E. H. (Ed.), Woven by the Grandmothers: Nineteenth-Century Navajo Textiles from the National Museum of the American Indian. Smithsonian Institution Press.

Wollan, M. (2011, May 18). Graffiti's Cozy, Feminine Side. The New York Times. Retrieved from

<http://www.nytimes.com/2011/05/19/fashion/creating-graffiti-with-yarn.html>. 